\title{
Resuscitation of Bio-Gas Technology in Guyana
}

Jagessar RC*

Department of Chemistry, Faculty of Natural Sciences, University of Guyana, South America

*Corresponding author: Jagessar RC, Department of Chemistry, Faculty of Natural Sciences, University of Guyana, South America

\section{Abstract}

There is an urgent need to resuscitate the production of bio-gas, as one of the alternative renewable sources of energy, in comparison to fossil fuels in Guyana. Bio-gas production in Guyana, started in the 1980s. However, since then, surprisingly this technology has dwindled over the years. Biogas is a mixture of different gases produced via the breakdown of organic matter in a Bio-gas digester in the absence of oxygen, with methanogenic organisms. It can be produced from raw materials such as agricultural wastes, manure, municipal wastes, plant material, sewage, green wastes or food wastes. Biogas is primarily methane $\mathrm{CH} 4$, and carbon dioxide (CO2) and may have small amounts of hydrogen sulphide, H2S, moisture and siloxanes. The gases methane, hydrogen, and carbon monoxide (CO) can be combusted or oxidized with oxygen. The energy release allows biogas to be used as a fuel. It can be used for any heating purposes, such as cooking. It can also be used in a gas engine to convert the energy in the gas into electricity and heat. Biogas can be compressed, the same way as natural gas is compressed and used to power motor vehicles. Agriculture and manure wastes are predominant in Guyana and this would form a good feedstock for the production of Bio-gas. There is a need for the installation of bio-gas digesters around the country, to utilize agriculture and bio-wastes etc. The Guyanese Diaspora and the Entrepreneurship Sector can aid in the resuscitation of this technology via the provision of finance for the construction and installation of Bio-gas digesters around the country. Such a venture can help Guyanese reduce their cost on energy for local consumption and at the same time, aid in keeping our environment clean of biotic wastes.

Keywords: Bio-gas technology; methanogenic organisms; agriculture waste; municipal waste; Diaspora; Entrepreneurship

\section{Introduction}

There is a need to intensify the production of renewable energy on our planet, considering that fossils fuel are dwindling even though in some countries like Guyana, hugh oil reserves have been found. However, no country in the world is secured with the use of intense fossil fuels considering that fossil fuel when burn produces significant amount of $\mathrm{CO} 2$ which amongst other greenhouse gases (GHG) contribute significantly to Global Warming which has been the source of many catastrophic hurricanes in the Caribbean and the United States. The amount of GHG emissions in the atmosphere is rising significantly, with $\mathrm{CO} 2$ the main contributor. Added to this, the global energy demand is increasing rapidly, with about $88 \%$ of the energy produced currently stems from fossil fuels. In this regard, bio-gas, as one of the alternative energy sources that can be of significant importance as an alternative energy to fossil fuel, currently and in the future. Biogas is a multilateral renewable energy source that can replace conventional fuels to produce heat and power. It can also be used as gaseous fuel in automotive applications. Biomethane, which is upgraded bio-gas can also substitute for natural gas in chemicals production. Bio-gas produced via anaerobic digestion (AD) provides significant advantages over all other forms of energy sources because anaerobic digestion is an energy-efficient and environmentally friendly technology $[1,2]$. In addition to fossil fuels, anerobic technology can reduce GHG emission by utilizing locally available feedstocks. The by-product of Bio-gas digestion called digestate is a high value fertiliser for crop cultivation and can replace synthetic fertilisers. Biogas Technology has reached its zenith in developed countries in Europe, United States, China and 
India. Guyana has an abundance of organic wastes which are a good feedstock for bio-gas production. Surprisingly, this technology which started in the mid1980 and was booming, has dwindled substantially. Maybe, Guyanese thinks of it as a primitive source of energy. However, its has been used significantly in the developed countries. For example, in Europe, the production of biogas reached 1.35 $x 107 \mathrm{t}$ in 2014 [3]. Germany is the pioneer country in global biogas production, with approximately $25 \%$ of installed capacity due to the strong development of agricultural bio-gas plants on farms. A survey in 2014 revealed that more than 8000 agricultural biogas production units were in operation in Germany [4]. Recent studies have shown that many European countries have established favourable conditions for the production of electricity production from biogas. The agro-biomass available for anaerobic digestion in Europe is of the value of $1.5 \times 109 t$ [5]. Other countries such as the United States of America, China and India are also investing in biogas production $[6,7]$.

\section{Production of Biogas}

Biomethanation involves the anaerobic fermentation of $\mathrm{CO}, \mathrm{CO} 2$ and $\mathrm{H} 2$ to methane. Bio-gas is obtained via the anaerobic fermentation of organic matter or organic wastes using selective microorganisms, which transform biomass waste into biogas (mainly methane and carbon dioxide) and digestate. Organic wastes are inclusive of agricultural wastes, manure, municipal waste, plant material, sewage, green waste or food waste. The reaction is carried out in Bio-gas digesters/Anaerobic digesters or Bio-gas plants. Anaerobic digesters are containers or enclosures from which oxygen has been restricted. However, there is an outlet for the gas. Bio-gas digesters can be constructed from drums, tins, concrete, bottle, etc. The gas can be collected with a separated gas collector or used directly from the digester. The digester can be operated as a batch or continuous process [8]. "A bio-digester unit is a clean, healthy and economic alternative since it not only provides fuel for domestic household use but also provides liquid and solid fertilizers that can be used in farming, thus reducing the amount of chemical contaminants affecting human health and the environment". The bio-digester unit also helps to reduce nesting grounds for flies and mosquitoes that could otherwise spread illnesses to humans. The cost to set up a bio-digester in Guyana, including parts and labour is approximately $\$ 120,000$ and would replace the need for at least one 20-Ib LPG gas cylinder per month. Bio-gas can also be produced as a Landfill gas (LFG) via the breakdown of biodegradable waste inside a landfill, resulting from chemical reactions and microbes.

\section{Composition of Biogas}

Bio-gas is the gas obtained when organic matter decomposes in the absence of oxygen. It is called bio-gas because it is obtained from biomass (plant and animal remains [9]. Pretreatments to enchance the digestibility of lignocellulosic biomass. Bioresour. Technol. 100. [10-18]. It is produced via the action of anerobic microorganisms on organic matter. The microorganism metabolise organic matter with the aid of enzymes, reducing the large molecules such as carbohydrates, proteins and fats into smaller molecules such as $\mathrm{CH} 4, \mathrm{CO} 2$ and $\mathrm{H} 2$.

Bio-gas is also known as marsh gas, sewage gas and dun gas. It is colourless and flammable with a characteristic odour. It contains methane $(45-80 \%)$, carbon dioxide (27-45\%), nitrogen $(0.5-3 \%)$, hydrogen $(1-10 \%)$, carbon monoxide $(0.1 \%)$, oxygen $(0.1 \%)$ and hydrogen sulphide in trace amounts. It has a calorific value of 5.5-7.5 kwh/m3. It rises slowly in air and then dissipates due to the factor that methane is slightly lighter than air. The composition of the gas is dependent on the nature of the material used. Plants tend to produce gas with more amount of carbon dioxide. The quality of the bio-gas produced also depends on the carbon to nitrogen $(\mathrm{C} / \mathrm{N})$ of the materials used. Bio-gas is difficult to compress. It requires as much as $34,000 \mathrm{KN} / \mathrm{m} 2$ to liquefy it. Bio-gas can be used for cooking, heating and running of machinery.

Table 1: The composition of Bio-gas.

\begin{tabular}{|c|c|c|}
\hline Compound & Formula & \% \\
\hline Methane & $\mathrm{CH}_{4}$ & $50-75 \%$ \\
\hline Carbon dioxide & $\mathrm{CO}_{2}$ & $25-50 \%$ \\
\hline Nitrogen & $\mathrm{N}_{2}$ & $0-10 \%$ \\
\hline Hydrogen & $\mathrm{H}_{2}$ & $0-1 \%$ \\
\hline Hydrogen sulfide & $\mathrm{H}_{2} \mathrm{~S}$ & $0.1-0.5$ \\
\hline Oxygen & $\mathrm{O}_{2}$ & $0-0.5$ \\
\hline
\end{tabular}

Bio-gas needs to be purified. Carbon dioxide and Ammonia are both removed by passing the gas through a solution of calcium hydroxide, $\mathrm{Ca}(\mathrm{OH}) 2$. Both of them react with the solution to give calcium carbonate and Ammonium carbonate respectively. Hydrogen sulphide is removed by passing the gas through a dessicant such as calcium chloride, 10. Calcium chloride can be regenerated by heating it to remove the water. Carbon dioxide is removed to increase combustibility of the gas. For cooking purposes, the gas may

Citation: Jagessar RC* . Resuscitation of Bio-Gas Technology in Guyana. Op Acc J Bio Sci \& Res 6(1)-2020. 
be used without scrubbing.

Bio-gas owes its use to entirely of the presence of methane in the gas. It is the major constituent of the gas, comprising $45-80 \%$. Methane, also known as marsh gas, is a gas at room temperature, with a boiling point of $-16^{\circ} \mathrm{C}$ and a melting point of $-180^{\circ} \mathrm{C}$. It is colourless, odourless and taseless gas. It has a density of $0.65 \mathrm{~g} / \mathrm{dm} 3$ at $20^{\circ} \mathrm{C}$ and is less dense than air. (Table 1 ) shows the typical composition of Bio-gas.

\section{Uses of Biogas}

Bio-gas, a renewable energy can be used for heating, electricity and many other operations that use a reciprocating internal combustion engine such as the $G E$ Jenbacher or Caterpillar gas engines [11] Biogas can be used for electricity production on sewage works, in a CHP gas engine, where the waste heat from the engine is used for heating the digester, cooking, space heating, water heating and process heating [12]. Biogas, if compressed, can replace compressed natural gas for use in vehicles, where it can fuel an internal combustion engine or fuel cells. It's a much more effective displacer of $\mathrm{CO} 2$ than the normal use in on -site CHP plants [13] Bio-gas if concentrated and compressed, can be used in vehicle transportation. Compressed Bio-gas is widely used in Sweden, Switerland and in Germany. The Bio-gas train Amanda has been in service in Sweden since 2005 [14]. Statistic data in 2007, shows that an estimated 12,000 vehicles were being fueled with upgraded biogas worldwide, mostly in Europe [15]. The biogas can be used for cooking, heating, lighting, electricity generation and can replace fossil-based energy sources such as liquefied petroleum gas (LPG).

\section{Biogas Feedstock Types}

There are several substrates that can be used for biogas production using anaerobic digestion technology. Biogas production from animal waste provides a unique opportunity to mitigate the effects of waste produced on farms while providing a cheap and sustainable source of energy. These include animal manure and slurry, sewage sludge, municipal solid waste and food waste. (Table 2 ) shows the production amount and energy potential for the different feedstocks that can be utilized for biogas production.

Bio-mass contains carbohydrates, proteins, fats, cellulose and hemicellulose, which can be used as feedstocks for biogas production. Co-substrates are usually added to increase the organic content and thus achieve a higher gas yield. Co-substrates include organic wastes from agriculture wastes, food wastes and municipal biowastes from households. The composition and yield of bio-gas
Table 2: Comparison of biogas yield and electricity produced from different potential substrates.

\begin{tabular}{|c|c|c|}
\hline Type & $\begin{array}{c}\text { Bio-gas yield } \\
\text { per ton fresh } \\
\text { matter }\left(\mathbf{m}^{3}\right)\end{array}$ & $\begin{array}{c}\text { Electricity } \\
\text { produced } \\
\text { per ton fresh } \\
\text { matter } \text { (kW.h) }\end{array}$ \\
\hline Cattle dung & $55-68$ & 122.5 \\
\hline Chicken litter/dung & 126 & 257.3 \\
\hline Fat & $826-1200$ & 1687.4 \\
\hline Food waste \\
(disinfected) & 110 & 224.6 \\
\hline Fruit wastes & 74 & 151.6 \\
\hline Horse manure & 56 & 114.3 \\
\hline Maize silage & $200 / 220$ & 409.6 \\
\hline Municipal solid waste & 101.5 & 207.2 \\
\hline Pig slurry & $11-25$ & 23.5 \\
\hline Sewage sludge & 47 & 96.0 \\
\hline
\end{tabular}

depend on the feedstock and co-substrate type [16]. Carbohydrates and proteins show faster conversion rates than fats to biogas. However, fats produce a higher Biogas yield [17-19]

\section{Disadvantages}

Biogas can be explosive when mixed in the ratio of one part biogas to 8-20 parts air. Special safety precautions have to be taken into consideration for entering an empty biogas digester for maintenance work. The bio-gas system should never have a negative pressure as this could cause an explosion. Negative gas pressure can occur if too much gas is removed or leaked.

\section{The Production of Bio-Gas in Guyana and Around the} World

Bio-gas is a key player in several countries in the world. These include countries in Europe, United States, China and India. The European Union Renewable Energy Directive advocate for a $10 \%$ increase in the use of green vehicle fuels by 2020. As such, European countries are encouraged to invest in biogas production. A large percentage of the electric power in Germany comes from bio-gas. Most biogas production is currently based on sewage sludge. It is estimated that by 2030, an increasing amount of biogas (about 224 TW.h) will be produced from wet manure, landfill, undigested sewage sludge and food processing residues [20]. Guyana Energy agency has been monitoring and supporting the installation of bio- gas digesters throughout the country. At present there are approximately thirty (30) bio-digesters installed in Guyana that use organic materials 
to produce biogas (GEA).

\section{Conclusion}

Bio-gas, a renewable source of energy, needs urgent revival in many countries of which Guyana is no exception. Countries should first resort to alternative source of energy, in order to phase out the use of fossil fuels. The latter is detrimental to the environment, being a chief source of global warming. In addition, countries fossil fuel stocks are depleting, even though, hugh reserves have been found offshore in Guyana.

\section{References}

1. Van Forest F (2012) Perspectives for bio-gas in Europe. Oxford: Oxford Institute for Energy Studies.

2. Nishio N, Nakashimada Y (2007) Recent development of anerobic digestion processes for energy recovery from wastes. J. Biosci Bioeng 103 (2): 105-112.

3. EurObservER (2014. The state of renewable energies in Europe. Report. Paris: EurObserver.

4. Wagner L (2015) Trends from the use of Bio-gas technology in Germany: In Proceedings of the VIV Asia Biogas Conference Bangkok, Thailand.

5. Edita Vagonyte (2015) Biogas \& Biomethane in Europe. Work package 4: Biogas \& Biomethane, Report, Brussels: European Biomass Association.

6. Soetaert W, Vandamme E (2009) Biofuels in perspectives. In Soetaert W. Vandamme EJ, editors Biofuels, New Jersey: John Wiley \& Sons, Ltd; 1-8.

7. Lin Y, Tanaka S (2006) Ethanol Fermentation from biomass resources: Current state and prospects. Appl Microbiol Biotechnol 69 (6): 627-642.

8. Dinsdale RM, Premier GC, Hawkes FR, Hawkes DL (2000) Two-stage anerobic digestion of waste activated sludge and fruit/vegetable waste using inclined tubular digesters. Bioresour. Technol 72: 159-168.
9. Hendriks ATW, Zeeman G (2009)

10. Kompogas (2011) Green energy from organic waste.

11. State Energy Conservation Office (Texas) (2009) "Biomass Energy: Manure for Fuel.", Archived from the original on the 23rd April.

12. Biogas CHP-Alfagy-Profitable Greener Energy via CHP, Cogen and Biomass Boiler using Wood, Biogas, Natural Gas, Biodiesel, Vegetable Oil, Syngas and Straw". Archived from the original on the 30th of April, 2015. Retrieved 15th, May, 2015.

13. Biogas CHP-Alfagy-Profitable Greener Energy via CHP, Cogen and Biomass Boiler using Wood, Biogas, Natural Gas, Biodiesel, Vegetable Oil, Syngas and Straw". Archived from the original on the 30th of April, 2015. Retrieved 15th, May, 2015.

14. Biogas train in Sweden Archived 29th September, 2011 at the Wayback Machine.

15. What is Biogas? U.S. Department of Energy, 13th, April, 2010.

16. Fachagentur Nachwachsende Rohstoffe (2012) Bioenergy in Germany: Facts and Figures. Report. Bonn: Federal Ministry of Food, Agriculture and Consumer Protection.

17. Braun R (2007) Anaerobic digestion: A multi-faceted process for energy environmental management and rural developments. In: Ranalli P, editor Improvement of crop plants for industrial end uses. Dordrecht: Springer 335415.

18. Braun R (1986) Biogas-Methane treatment of organic waste Wien: Springer; Germany; Zubr J. Methanogenic fermentation of fresh and ensiled plant materials. Biomass 11(3): 159-171.

19. Msangi S (2012) Biofuels and a green economy. Washington.

20. European Environmental Agency (2006) How much bioenergy can Europe produce without harming the environment? Report. Copenhagen: European Environmental Agency.

*Corresponding author: Jagessar RC, Email: raymondjagessar@yahoo.com

Next Submission with BGSR follows:

- Rapid Peer Review

- Reprints for Original Copy

- E-Prints Availability

- Below URL for auxiliary Submission Link: https://biogenericpublishers.com/submit-manuscript/ 